\title{
Ritual plants of Muslim graveyards in northern Israel
} Amots Dafni*1, Efraim Lev ${ }^{2}$, Sabine Beckmann ${ }^{3}$ and Christian Eichberger ${ }^{4}$

\begin{abstract}
Address: ${ }^{1}$ Institute of Evolution, University of Haifa, Haifa, 31905, Israel, ${ }^{2}$ Department of Eretz Israel Studies, University of Haifa, Haifa, 31905 , Israel, ${ }^{3}$ Vigla Panagias, 72100 Agios Nikolaos, Crete, Greece and ${ }^{4}$ Department of Organismic Biology, University of Salzburg, Hellbrunnerstr. 34, A-5020 Salzburg, Austria
\end{abstract}

Email: Amots Dafni* - adafni@research.haifa.ac.il; Efraim Lev - efraiml@research.haifa.ac.il; Sabine Beckmann - sanibe@agn.forthnet.gr; Christian Eichberger - christian.eichberger@sbg.ac.at

* Corresponding author

Published: 10 September 2006

Journal of Ethnobiology and Ethnomedicine 2006, 2:38 doi:10.1186/1746-4269-2-38

This article is available from: http://www.ethnobiomed.com/content/2/I/38

(c) 2006 Dafni et al; licensee BioMed Central Ltd.

This is an Open Access article distributed under the terms of the Creative Commons Attribution License (http://creativecommons.org/licenses/by/2.0), which permits unrestricted use, distribution, and reproduction in any medium, provided the original work is properly cited.
Received: 3I May 2006

Accepted: 10 September 2006

\begin{abstract}
This article surveys the botanical composition of 40 Muslim graveyards in northern Israel, accompanied by an ethnobotanical study of the folkloristic traditions of the use of these plants in cemeteries.

Three groups of plants were found to be repeated systematically and were also recognized for their ritual importance: aromatics herbs (especially Salvia fruticosa and Rosmarinus officinalis), white flowered plants (mainly Narcissus tazetta, Urginea maritima, Iris spp. and Pancratium spp.) and Cupressus sempervirens as the leading cemetery tree.

As endemic use we can indicate the essential role of $S$. fruticosa as the main plant used in all human rites of passage symbolizing the human life cycle. The rosemary is of European origin while the use of basil is of Indian influence.

The use of white flowers as cemeteries plants reflects an old European influence and almost the same species are used or their congeners. Most of the trees and shrubs that are planted in Muslim cemeteries in Israel have the same use in ancient as well in modern European cultures.

In conclusion, our findings on the occurrence of plants in graveyards reflect the geographic situation of Israel as a crossroads in the cultural arena between Asia and Europe. Most of the traditions are common to the whole Middle East showing high relatedness to the classical world as well as to the present-day Europe.
\end{abstract}

\section{Background}

Plants were used to mark rites of passage both in human and in the annual cycle, as well as to decorate and to symbolize [[1]:262]. Plants, especially flowers, have been used at funerals in many cultures [[1]:66-70; [2]:165-167; [3]: 3-5]. Folkard [[4]:193] wrote, "All nations at different periods seem to have delighted to deck the graves of their departed relatives with garlands of flowers. The association of certain trees and plants with death and its gloom- ing surrounding dates from a period remote and shadowy in its activity".

A century later Vickery [[5]:196] noted: "Flowers symbolize human mortality, and are equally symbolic of resurrection and rebirth, springtime and autumn, renewal and decay, and have long continued to provide consolation and hope at critical times in man's life". 
In the New Kingdom of Ancient Egypt (16 - 12 centuries BC.) flowers of a particular sacred tree were considered life giving, so they were called "flowers of life". These flowers, and flowers of lotus, were used in funerals. Statues and coffins of the deceased were decorated with garlands of flowers [[6]:89].

According to Folkard [[4]:194] "The flowers strewed over graves by the Greeks were the Amaranth, Myrtle, and Polyanthous (=Narcissus)... The ancient Christians would choose different plants according to the age of the dead person: the flowers so used were deemed typical of the dead: to the young were assigned the blossoms of spring and summer, to middle age, aromatic herbs and the branches of primeval trees".

Roman funerals demanded a lot of flowers. The corpse was adorned as an expression of honour and affection. The funeral urn was similarly decorated. Flowers were scattered on the guests at the funeral banquet, and wreaths of dry and artificial flowers were placed at the tomb. After the funeral, fresh flowers, especially roses, lilies and violets, were used to deck out tombs as a memorial to show that the dead were still remembered [[1]:67; [4]:195; [7]:151].

The ancient Israelites differed from other religions: "The culture of flowers had put down deep roots in most societies of the Mediterranean and the Near East, being rejected only by ancient Israelites. As we have seen the Israelites accepted neither the sacrifices made to their neighbour's gods nor the garlands that accompanied these offerings" [[1]:70]. Therefore, as a rejection of their neighbours' "idolatry", they did not display flowers or plants at their ceremonies. In modern times Orthodox Jews do not use flowers in ceremonies, synagogues, cemeteries or even in houses [[1]:46-47]. Vickery [[5]:187] mentioned "In communities where burial takes place very soon after death, as is the case with Orthodox Jews, flowers are rarely associated with mourning, and the substitutes are mainly stones". While Goody [[1]:46-47] stated "Down today one finds stones not flowers in the cemetery, and then as reminder rather than offering". Secular Jews bring garlands of flowers and leave them on the tombs, but the ultra-religious are forbidden to plant any plant or flower upon graves [[8]: IIV; 34-35].

Interestingly, several authors [9-11] dealing with Muslim funeral customs, don't mentioned any ceremonial use of plants of any kind. While Spoer and Spoer [[12]:131] mentioned that "sweet smelling herbs" are placed on graves in Palestine.
The present article is a survey of the plants ritually used in Muslim graveyards of in northern Israel in the context of their cultural and ethnobotanical background.

\section{Methodology}

The field study (1999-2005) was carried out in 35 Muslim villages in northern Israel, mainly in the Galilee. Field observations included recording plant species in the graveyards. Oral interviews were held with 80 informants, 48 who are cited personally (Appendix 1 ). The average age of the informants was 59.3 ( $S D=18.1$ ) years. Respondents were 41 males and seven females. In general women were reluctant to be interviewed, and when they agreed the interview was held in the presence of other family members.

The informants were mainly chosen according to their knowledge of common traditions and/or religious status. In each village we made a preliminary survey to locate people who are regarded as well immersed in local traditions and/or in religious customs.

The informants were asked about the ritual and religious importance of the plants found in the cemeteries, and why they were planted there. We used interview techniques to avoid a non spontaneous atmosphere and to overcome the reluctance of the informants to cooperate, Most informants refused to be videotaped or tape recorded. The botanical survey covered 40 cemeteries. We tried to avoid modern irrigated plots, on which many ornamental plants are grown. Cemeteries older than 50 years were considered "traditional". For each cemetery we listed the 20 most common plant species. Two parameters were calculated for each plant species: frequency (percentage of cemeteries in which the plant species appears) and dominance (percentage of cemeteries in which the species is the most common one).

\section{Results}

We divided the list of recorded plants and the oral information gathered at the cemeteries into three categories based on the botanical characters of the plants: 1 . Plants with aromatic leaves (Table 1); 2 . White-flowered plants (Table 2) and 3. Trees and bushes (Table 3). These categories were found to correlate, more or less, with oral ethnobotanical evidence.

\section{Aromatic plants}

Data concerning the presence of aromatic plants in the surveyed cemeteries are presented in Table 1 . The following points emerge:

1. On average, $6.0(\mathrm{SD}=4.3$; range $0-14)$ aromatic species were present in each cemetery. 


\begin{tabular}{|c|c|}
\hline Species & $\begin{array}{l}\text { Frequency } \\
\text { and domir }\end{array}$ \\
\hline $\begin{array}{l}\text { Three-Lobed Sage - Salvia fruticosa Miller } \\
\text { (=S. triloba L.f) (Lamiaceae) }\end{array}$ & $93.1(68.9 *)$ \\
\hline $\begin{array}{l}\text { Rosemary - Rosemarinus officinalis L.** } \\
\text { (Lamiaceae) }\end{array}$ & $62.0\left(10.3^{*}\right)$ \\
\hline Basil - Ocimum basilicum L. **^ (Lamiaceae) & 65.5 \\
\hline Mint - Mentha spp.** (Lamiaceae) & 50.0 \\
\hline
\end{tabular}

Myrtle - Myrtus communis L. (Myrtaceae)

Rue - Ruta chalepensis L. (Rutaceae)

Lemon verbena - Lippia citroiodora (Ort.) HBK ** (Verbenaceae)

Rose - Scented Geranium - Pelargonium

graveolens (L.) L'Her ex Ait. **

m (Geraniaceae)

$0^{-}$White-Leaved Savory - Micromeria fruticosa

(L.) Druce (Lamiaceae)

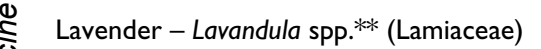

Tagetes - Tagetes sp. **^ (Asteraceae)

Wormwood - Artemisia arborescens L.* (Asteraceae)

Jasmine - Jasminum sp.** (Oleaceae)

ठे

Thyme - leaved Savory Satureja thymbra L. (Lamiaceae)
References from the Middle East and adjacent countries

symbols and death myths)

S. officinalis (Europe [20, I:666]; England; [14:102])

Iraq and Iran (the Christian section of the Mandanean [17:183])

Ancient times [20; II:645-647]; Europe [2:168; 4:196], England [15:428,438; 56:138; 60:144; 61:150-15I]; Cyprus [5:184,187,188]

Iran [5I:191; 28:157]; Egypt [23:95]

Italy and Greece [20;II:54,]; India, (0. sanctum) [26:17-18; 62:22;])

Ancient Egypt [22:2।4-2।5; 63:|20]; Ancient Minoan [64:6]; Ancient Greece [20;II:366; $65: 121 ; 66: 518 ; 67: X I X]$

Lybia [23:319]; Turkey [68:187; 69:62]; Syria [12:131]

Ancient Greece [ $4: 194 ; 21: 54 ; 58: 14,82 f ; 65: 49 ; 70: 12,123 f f ; 71: 8,94 f, 426 ; 72:$ passim; 73:15,33; 74:tab 154; 75:18]; Rome [2:167; 4:465,476,487; 20;1:442; 21:54; 37:144; 76:49, 77:30]; Spain (Muslims, 15th century, [78:39]); England (16-17th centuries, [14:102])

Spain [66:24I]; England [5:184; $11: 102]$

England [5:184-185]

Lybia [4:191] 
Table 2: Plants used in graveyards - white-flowered plants.

\begin{tabular}{|c|c|c|c|}
\hline Species & $\begin{array}{l}\text { Frequency of } \\
\text { appearance (\%) }\end{array}$ & $\begin{array}{l}\text { Reference from the Middle } \\
\text { East and adjacent countries }\end{array}$ & $\begin{array}{l}\text { References from other regions (also for } \\
\text { funerals, immortality and mourning } \\
\text { symbols, and death myths). }\end{array}$ \\
\hline $\begin{array}{l}\text { Narcissus - Narcissus tazetta L. } \\
\text { (Amarylliadaceae) }\end{array}$ & 41.3 & & $\begin{array}{l}\text { Ancient Greece [21:68-269; 35:248; 36:430; } \\
\text { 37:1 48]; Rome [77:3।]; England [30:148] }\end{array}$ \\
\hline $\begin{array}{l}\text { Sea squill - Urginea maritima (I.) } \\
\text { Baker (Liliaceae) }\end{array}$ & 37.9 & & \\
\hline $\begin{array}{l}\text { Day Cestrum - Cestrum diurnum L. } \\
\text { (Solanaceae) }\end{array}$ & 27.5 & & \\
\hline $\begin{array}{l}\text { Iris-Mainly Iris albicans W. Barley } \\
\text { and I. mesopotamica Dyes } \\
\text { (Iridaceae) }\end{array}$ & 24.1 & $\begin{array}{l}\text { Palestine }[39: 296 ; 81: 812] \text {; Syria } \\
\text { (16th century, [82:63]; North } \\
\text { Africa [S. Jury Pers. Comm.] }\end{array}$ & $\begin{array}{l}\text { Muslim cemeteries from Spain to Kashmir [21:64- } \\
65] \text {. India [Muslims, 78:39] }\end{array}$ \\
\hline $\begin{array}{l}\text { Sea daffodil-Pancratium maritimum } \\
\text { L. and P. parviflorum Delile } \\
\text { (Amaryllidaceae) }\end{array}$ & 22.2 & & Late Minoan [7:176-184] \\
\hline Rose - Rosa sp. (Rosaceae) & 20.0 & & $\begin{array}{l}\text { Ancient Greece and Rome (Red flowers! [83:219] } \\
\text { and references therein); England [5:184-185; } \\
\text { 14:102] }\end{array}$ \\
\hline $\begin{array}{l}\text { White Arum-Lily - Zantedeshcia } \\
\text { aetiopica Sprengl. (Araceae) }\end{array}$ & 20.0 & & France $[1: 284]$ \\
\hline $\begin{array}{l}\text { Asphodel - Asphodelus ramosus } \\
\text { Miller (=A. aestivus Brot.) } \\
\text { (Liliaceae) }\end{array}$ & 6.8 & Turkey [75:18] & $\begin{array}{l}\text { Minoan Crete [84:55]; Ancient Greece, (symbol of } \\
\text { death, [21:65; 38: XI, 539-543, XXIV, I3;], planting } \\
\text { on graves [3I:157; 75:18; 85:62], as a funeral plant, } \\
\text { [86:300]). Modern Greece [87:100-10I]. }\end{array}$ \\
\hline $\begin{array}{l}\text { Virgin Mary Lily - Lilium candidum } \\
\text { L. (Liliaceae) }\end{array}$ & 0 & & $\begin{array}{l}\text { Rome [77:30]; Europe [20, II:324]; Germany } \\
{[31: 12] \text {; England [14:102;30:228] }}\end{array}$ \\
\hline
\end{tabular}

2. Half of the recorded species were members of the family Lamiaceae.

3. Only one cemetery had no aromatic plant.

4. The most frequent as well as dominant species in cemeteries was Salvia fruticosa and the second was Rosmarinus officinalis.

5. In 18 cemeteries wreaths of aromatic plants were placed on the fresh graves at the funeral and/or during later visits (especially Salvia and Ocimum).

6 . The presence of wild aromatic plants in the nearby natural habitats did not correlate with species diversity of such species on graves. In fact, $66 \%$ of the aromatic species in cemeteries were not indigenous.

7. In the traditional cemeteries all the plants were perennial, only recently the adoption of irrigation systems allows maintenance of annuals such as basil (Ocimum).

8. In the old traditional cemeteries (mostly abandoned or neglected today) $S$. fruticos $a$ and $R$. officinalis were almost the only aromatic species present.

In attempt to uncover the possible role of Salvia fruticosa's use in funerals and cemeteries informants were asked "Why is S. fruticosa used in funerals and planted at graves?". We received the following answers (Bold number in parenthesis indicates the informant identity, see Appendix 1):

1. "The angels like a good odour and come to the fragrant plants, and they also transfer the prayers to the dead" (7). "We place Salvia in cemeteries because it gives a good odour. When a person is deceased the angels come to visit him and they like good odour - that is why we put Salvia there" $(7,8,16,19)$. This note is related to the common belief that angels go to judge the dead person in his grave [[10]:74; [11] passim; [12]:130,134].

2. "Fragrant plants are planted in cemeteries to counteract the unpleasant smell; we have to recall because the burial was superficial" (15). "For a good odour in the cemetery" $(17,28,33,36,38,41,43,49)$.

3. "We put Salvia on graves because it gives medicine, "barakeh" (a divine blessing) and good odour" $(11,12,13,14$, $18,20,21,24,29)$. "Because it is a blessed and sacred plant that gives good odour and it is healing" $(15,21,25$, $26,34,43,44)$.

4. "Because it is evergreen and has a good odour" $(26,30$, $40)$.

5. "As a token of honour and appreciation for the deceased" $(9,24,39)$. 
Table 3: Plants used in graveyards - trees and shrubs.

\begin{tabular}{|c|c|c|c|}
\hline Species & $\begin{array}{l}\text { Frequency of } \\
\text { appearance and } \\
\text { dominance (\%) }\end{array}$ & $\begin{array}{l}\text { References from the Middle } \\
\text { East and adjacent countries. }\end{array}$ & $\begin{array}{l}\text { References from other regions (also for } \\
\text { funerals, immortality and mourning } \\
\text { symbols and, death myths) }\end{array}$ \\
\hline $\begin{array}{l}\text { Cemetery Cypress - Cupressus } \\
\text { sempervirens L. (Cupreessaceae) }\end{array}$ & $68.9(20.6 *)$ & $\begin{array}{l}\text { Iran [86:18; 88:132; 89:30]; Turkey } \\
\text { [42:182; 69:63; 91:350; 92;11:21; } \\
93: 219 ; 94: 115 ; 95: 136,146] ; \\
\text { Lebanon [96:205]; Egypt [97:431] }\end{array}$ & 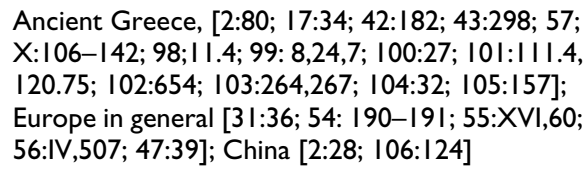 \\
\hline $\begin{array}{l}\text { Olive - Olea europaea L. } \\
\text { (Oleaceae) }\end{array}$ & 41.3 & & $\begin{array}{l}\text { Ancient Greece [3:308; 100:27; 107:4.84] and also } \\
\text { Rome [56: 230; } 20,11: 500 ; 89: 373]\end{array}$ \\
\hline $\begin{array}{l}\text { Date palm - Phoenix dactylifera } L \text {. } \\
\text { (Palmae) }\end{array}$ & 37.5 & $\begin{array}{l}\text { Egypt [109;I: I 32; I I0:464; } \\
\text { II।:43।] }\end{array}$ & Europe $[2: 9 ; 20 ; 1: 129 ; 45: 191]$ \\
\hline Ficus - Ficus spp. (Moraceae) & 22.5 & & \\
\hline $\begin{array}{l}\text { Butcher's Broom - Ruscus } \\
\text { aculeatus L. (Dioscoreaceae) }\end{array}$ & 20.0 & & \\
\hline $\begin{array}{l}\text { Oleander - Nerium oleander } \mathrm{L} . \\
\text { (Apocynaceae) }\end{array}$ & 20.0 & & Rome $[77: 30]$ \\
\hline $\begin{array}{l}\text { Carob - Ceratonia siliqua } \mathrm{L} . \\
\text { (Caesalpiniaceae) }\end{array}$ & 20.0 & & \\
\hline $\begin{array}{l}\text { Christ's Thorn Jujube - Ziziphus } \\
\text { spina-christi (L.) Desf. } \\
\text { (Rhamnaceae) }\end{array}$ & 10.0 & Middle East [50:passim] & \\
\hline Fig - Ficus carica L. (Moraceae) & 10.0 & & England (19th century [14:102]) \\
\hline $\begin{array}{l}\text { Laurel - Laurus nobilis } L \text {. } \\
\text { (Lauraceae) }\end{array}$ & 2.5 & & $\begin{array}{l}\text { Ancient Greece [3:107-108; 45:191]; Rome } \\
\text { [77:30]; Europe in general [20, I:174; 108:174; } \\
\text { I। } 2: 174] \text {; England [14:102; 15:438; 30:7]; }\end{array}$ \\
\hline
\end{tabular}

$*=$ As a dominant plant

6. "Because of its good odour, beauty, and medicinal power " $(20,31,35,48)$.

7. "It has fragrance; it is a beloved and respected plant. It accompanies man during all stages of his life" $(15,18,32$, $33)$.

8. "We purify the dead with Salvia and for good odour" $(10,38)$.

9. "It expels the Satan and the evil eyes" $(7,19,23,33,45$, $47,48)$.

10. "There is justice in this plant" (34).

11. "For the blessing of the dead" (48).

Three-Lobed Sage (Salvia fruticosa) has an important role in daily rituals in the Muslim life-cycle in Israel and today it accompanies each person as a main ritual plant from birth to death:

1. When an infant is born he is placed on a bed of fresh leaves of three-lobed sage, and the mother drinks threelobed sage tea $(1,7,15,24,34,37)$. When infant is born a ceremony called mauled is performed. A sheep is slaughtered and all the friends and the relatives are invited. The Sheikh arrives and reads chapters from the Quran. A sub- stantial number of three-lobed sage leaves are mixed with barley and placed on a tray near the Sheikh. The Sheikh reads the (appropriate) chapter and each of the guests takes a fistful of the mixture in a small packet. At home this mixture is used to prepare an incense against evil eye and demons; it is placed on burning coals and then the house is blessed with a good fragrance and the demons are expelled $(1,12,27)$.

2. At every wedding, and any other family feast, incense of three-lobed sage leaves is placed on burning coals. It is used against evil eye and to expel demons $(1,2,18,27)$.

3. Garlands of three-lobed sage for incense are left at the graves of saintly people as well as in front of sacred trees, for the private use of the visitors who pray and burn incense in honour of the holy man (A. Dafni personal observations).

4. Garlands of three-lobed sage are used in funerals and also placed at graves; the dead body is placed on a layer of fresh three-lobed sage leaves $(2,24,34,42)$.

One informant (15) summarized the importance of threelobed sage in the daily local ritual: "By placing three-lobed sage on the graves, a connection is sustained from birth to death", while another person (27) said "The three-lobed sage accompanies man in all stages of his life". 


\section{White-flowered plants}

Data concerning the presence of white flowered flowers species in the surveyed cemeteries are presented in Table 2. We report the the following trends:

1. White flowers are more common in old traditional cemeteries, some of which are abandoned or neglected today.

2. The commonest white-flowered plants in traditional graveyards are Iris spp.

3. Today the most common plants in new cemeteries are Narcissus tazetta and Urginea maritima.

4. White flowered species are usually taken from the local nearby vegetation. Pancratium maritimum may be found in cemeteries along the seashore, which is their original habitat, while Pancratium parviflorum is evident in cemeteries near calcareous habitats, in which it grows naturally.

5. Narcissus tazetta (and other white cultivars) and Iris spp. are scattered without any clear geographic or ecological pattern.

6. Asphodelus ramosus is quite rare as a graveyard plant.

7. All the species in this group are perennial geophytes, which need no cultivation.

When we asked the informants "Why are white flowers planted on graves?" we received the following answers:

1. "White flowers are signs of "something good" (26).

2. "White is the way to Paradise" (28).

3. "White flowers are pure like the soul of the deceased" (4). "The white colour a sign that a man is pure and clean" (10).

4. "The white flower recalls the colour that characterizes the Haj, white colour is beloved by God, and white colour will erase the deceased's sins" (7).

5. "Because of the beauty, and to honour the deceased.... white colour .... A bride wears white, every dead person is wrapped in white cloth, the pilgrims to Mecca wear identical white clothes to show that all are equal" (8).

6. "White colour is the colour of birth (the baby is wrapped in a white cloth), of a wedding (the bride's dress), and of death (the white shroud)...life commenced with white and ended with white (27).
7. "The white flower recalls the colour of the pilgrim's garment ...white is preferred by God and will redeem the dead person" (34).

8. In this connection we heard the following story "A king had a lovely daughter. One day the daughter was violated, and a girl who disguised herself a boy was accused of the rape. When the head of the accused girl was cut off, her real identity was disclosed and the people regretted their deed. Zambak (a general name for white flowers like Lilium, Iris and Pancratium) flowers were planted on the daughter's grave. Because the raped daughter had acquiesced to the violation she was buried and a carob tree (which is regarded as a 'bad tree') was planted over her grave" (5).

\section{Trees and shrubs}

Data concerning the presence of trees and bushes in the surveyed cemeteries are presented in Table 3. From our observations and Table 3 we can conclude:

1. Cypress is the most frequent (68.9\%) as well as the only dominant plant $(20.6 \%)$. It is planted especially as a fence round cemeteries and also between graves. In old traditional cemeteries, cypress is almost the only tree.

2. Palms and olives are planted among graves and branches of both species are frequently placed on fresh graves. An interesting feature is the abundance of palm branches placed on tombs on 'Id el-fitr (the feast at the end of Ramadan).

3. Ziziphus spina christi is not planted but is a component of the natural vegetation.

4. Several species of cultivated fruit trees are planted today in cemeteries (e.g. pomegranate, oranges, almonds, mulberry, and loquat); at present it is hard to see any pattern in this trend.

5. In one Bedouin village (Arab al Aramshe, 40-43), branches of Laurus nobilis are placed on graves.

6. In one Village (Akhbara), young shoots of Myrtus communis are placed on fresh graves (46-48, and our personal observations). In this village myrtle is grown commercially for the Jewish religious market for use at the Tabernacle Festival.

The following answers were given, by the informants, to our question, "Why are trees planted in graveyards?"

1. "Shrubs and trees are planted on graveyards to create a connection between the deceased and his God" (21). 
2. "Each tree protects the grave because it is green - a protection against evil events" (18).

3. "Every planted tree on a grave is praising the merciful god, on behalf of the deceased, all the time" (27).

4. "Green trees reduced the punishments inside the grave" (39).

\section{Discussion and conclusion Aromatic plants}

The custom to put aromatic plants in cemeteries is deeprooted in human history (Table 1). One may point out three reasons for the use of aromatic plants in cemeteries as well as in funerals.

1: Seaton [[13]:11] explained the use of aromatic as follows" Flowers, especially aromatic ones, played a hygienic role in handling of the dead in those days before embalming. While according to others: "Aromatic herbs and strongly scented flowers may suggest the original use of funeral flowers... to mask the odour of decaying flesh" [[5]:186-187]. " Aromatic herbs and strongly scented flowers were invariably used to hide the odour of decay in the days when the dead were laid out, often several days, in private houses before burial" [[14]:101] see also [[4]:189] concerning Wales, [[15]:428] for England and [[16]:47] for ancient Greece, Rome and Arabia). In Iraq and Iran the Christian sect of the Mandaeans used to smell sweet smelling flowers "so that the smell of death shall not reach them" [[17]:183]. The Armenians in Constantinople would plant Turpentine Terebinth (Pistacia terebinthus $\mathrm{L}$.) on graves and use the aromatic resins to mask the smell from the graves [[18]:67]. It is noteworthy that in Rome perfumes were used in funerals for the same purpose [[19]:286]. Our findings corroborate this general trend.

2. De Cleene and Lejeune [[20]: I: 647] explain the use of rosemary in funerals: "It was in fact...that its aroma conserved the dead body and that its evergreen leaves guaranteed immortality. Since incense was expensive, there was a preference for the aromatic Rosemary in religious ceremonies in antiquity, especially burial" (see also [[21]: 89; [22]:315]).

3. The main aromatic plants have a special ritual importance throughout the human rites of passage, from birth through weddings to the grave.

To summarize the informants' views on S. fruticosa one may recognize the respect devoted to these specific plant as an important medicinal, as well as a ritual plant that accompanied man from birth to death. The informants indicated the special reverence to $S$. fruticosa as a blessed plant beyond its physical qualities. There were some nuances and different views among the informants, but all expressed the high importance of this plant in daily life. Hardly any cemetery is devoid of the prevalence of this species (Table 1).

Rosemary has been very common in Europe as a funeral plant since ancient times [[20], II: 645-647; [22]:315316] and was used at weddings as well [[5]:364; [20], I:647-648], the explanation given is "It may seem surprising to learn that the plant's symbolism is linked to birth, sexual capacity and death". The reason for this is probably to be found in the belief that this aromatic plant keeps at bay evil spirits, which might otherwise exercise their harmful influence at life's important rites of passage (birth, marriage, and death) [[23]:191-192].

Several species of basil, especially "tulsi" (Ocimum sanctum L.), are regarded as the most sacred plants in the Hindu religion and therefore Basil is found in almost every Hindu house throughout India. The leaves are used for different ceremonies as: births, and weddings, sacred rituals, as well as in funerals [[24]:44-45; [25]:34-35; [26]:38-39].

Zohary and Grebel [[27]:613-614] noted the ritual role of the myrtle as a funeral as well as a wedding plant in Europe. In Judaism it is well known as a wedding plant (Jerusalem Talmud, Peah, 1: 15, and 4). In our survey we found that myrtle is commonly planted in graveyards (Table 1.) but only in one village young shoots are placed directly on the graves.

\section{White flowered plants}

White flowers are used in cemeteries and funeral due to the following reasons:

1. The white colour is a symbol of purity. According to Puckle [[2]:169] the fact that white flowers are almost exclusively used at funerals reminds us that they are a special token of purity. Our informants stressed the role of white colour as a symbol of purity and the rites of passage in human life as a reason why white flowers are planted on graves. Crowfoot and Baldensperger [[28]:126] recorded a story that clarifies this trend. An innocent girl from the village of Artas (in the Judean Mountains) was killed by her brother, who claimed that she had brought the family fame into disrepute. A white flower, "as it were the flower of gourd plant climbing upwards", grew on her grave and all the people of the village and the area knew and said it is because she was innocent. We found a similar story, which reaffirms the popular belief that white flowers are emblem of the purity of the deceased. White flowers were frequently used for funerals and as graveyard plants in Europe [[29]:157; [30]:220-221, 228, 253]. In 
German folklore the soul was supposed to take the form of a flower, such as a lily or a white rose. White lilies are said to spring from the grave of one unjustly executed as a token of the person's innocence [[31]:12]. In Britain white flowers are "funeral flowers" and must not be brought indoor [[32]:63].

Although the Madonna Lily (Lilium candidum L.) was not found in our survey it is worth mentioning in this context. The lily was popular among the Greeks and Romans, and was dedicated by the Christian Church to the Madonna, probably because its delicate whiteness was considered a symbol of purity [[33]:482].

According to De Cleene and Lejeune [[20], II: 324] the lily became a flower of death, graves, and the churchyard in Europe. It is preferably planted on the graves of children and virgins. As a grave flower it also symbolizes love, which transcends death. According to our survey the lily is apparently a "Christian plant" and not used by the Muslims for any ritual uses. As a wild plant it is very rare locally, although the cultivated species is quite common in Christian monasteries. Lily images can be found in Christian cemeteries engraved on gravestones (e.g. the Templar Cemeteries in Haifa as well as in Jerusalem: A. Dafni (Personal observations 20.4.2004 and 13.6.2004 respectively), as in Christian graves in the States [[34]:283-284].

2. Old myths related to the underworld - In the Greek Mythology narcissus is related to the underworld. Gaia, to please Hades, made the narcissus (Narcissus poeticus L.) grow so that its sweet perfume would entice Persephone, the daughter of Demeter into the underworld. This myth, in association with the scent of the narcissus, goes back the custom that has persisted to modern times of bedecking the dead and their graves with these flowers [[21]:68$69 ;[35]: 248]$. When the dead went into the presence of the gods of the underworld, they carried crowns of narcissus that those who mourned had placed in their white hands when the last good-byes were said [[37]:148].

Asphodel was mentioned in Homer [[38]; xi, 539, 543; xxiv, 13] as growing in the meadows of the land of departed [[21]:65]. The Greeks also planted asphodel round their graves, as the fleshy roots of these plants were supposed to nourish the dead [[1]:191; [31]:157].

Iris accompanied the souls of mortals to their rest along a path made by the rainbow, whose iridescent colours the iris possesses [[21]:64-65].

The Sea Squill is very common especially in old cemeteries as a connection to God as "messengers of the praying to the dead" (owing to its very deep roots). One of the local names basl el maytin (bulb of the dead) reflects this popular belief [[39]:295-296; [40]:87], it is also called "basl el makbara" (the cemetery's bulb, 18, 25).

3. White is the Muslim colour of mourning - This explains the occurrence of irises from Spain to Kashmir [[21]:6465] as well as in North Africa (S. Jury, University of Reading, Pers. Comm. 18.10.05)., as we already found.

4. Symbol of repentance - In Britain roses (usually white), rue, hyssop, thyme, or wormwood, all considered symbolic of repentance, and were arranged on coffins [[5]:184-185].

\section{Trees and shrubs}

Some trees and shrubs are planted in graveyards due the following reasons:

1. Evergreen plants - These shrubs and trees are symbol of eternity, according to Puckle [[2]:167], (see also [[42]:182] for cypress). The ongoing custom of planting certain kinds of trees in graveyards is due to their appearance, which by association promotes their use as symbols of immutable grief. Myrtle was regarded to have "sombre appearance" [[2]:99] and cypress as "dark and gloomy...to express sorrow [[58]:18]. Cypress was planted in cemeteries also because its dark green branches [[43]:154; [52]:194]

Evergreen trees were carried at funerals as a symbol of the soul's immortality. Jenner [[43]:154] mentioned "...the cypresses. From its not losing its leaves in wind it has adopted as the image of the just man who preserved his virtue.... In this significance it was placed on gravestones...from its dark and sombre colouring it has been used as a symbol of mourning and death, and it is almost universally used in cemeteries ".

In England until the $19^{\text {th }}$ century mourners customarily followed the corpse to the grave carrying rosemary, ivy, laurel, and other evergreens as a sign of immortality [[14]:102]. According to Maurin [[44]:196] evergreen foliage in cemeteries is held in contrast to the decay of the body. Folkard [[4]:189] noted "the belief in a future existence doubtless led to the custom of planting trees on tombs, especially the cypress, which was regarded as typical both of life and death. The tree growing over the grave, one can easily imagine, was looked upon by the ancients as an emblem of the soul departed become immortal".

The Greeks considered the myrtle a symbol of love and immortality, due to its evergreen character [[2]:167; [20]: 2003 I: 442; [37]:144]. 
2. Triumphal species - Laurel and date palm were use in Europe at funerals to "symbolize victory over adversity in life" [[45]:191], (see also [[2]:99; [20]: I; 129; [46]: 375]). In many cultures the date palm is a symbol of military victory and eternal fame. In funeral wreaths the palm is a mark of honour for the deceased. This wreath also symbolizes triumph over death [[2]:168; [20]: II: 213]. In later Greek mythology date palm is closely associated with Apollo and his twin sister Artemis as well as Athena. Therefore the date palm often appears as a symbol of light and victory [[35]: 48ff]. Cypress is frequently represented on ancient gravestones [[47]:13]. The unusual combination of cypress branches with palm fronds represents the triumph over death [[20]: II: 401]. Today, on Mount Kackar (North-eastern Turkey), there are depictions of the cypress tree on tombstones of men (A. Dafni personal observations).

3. Remnants of tree worship - Puckle [[2]:165] related trees in cemeteries to tree worship. Planting certain trees in the churchyard and cemetery is an almost a universal custom. In Israel tree worship is still widespread, and many of the trees are associated with graveyards and are especially venerated $(50,51,52,[[48-50]$, passim] $)$.

4. Trees are mentioned in religious scripture - Ziziphus spina christi (L.) Desf. has a special role as a cemetery tree due to its being mentioned in the Quran (LIII: 13-18; LVI: 28-32) under the name of "lote tree" [[51]:65-74] and, accordingly, this species is highly respected by the Muslims through the Middle East [[50]: passim]. In several countries [[50] and references therein] the bodies of dead Muslims were washed with water in which the leaves of Ziziphus spina - christi were soaked. That is the reason why this species is kept in cemeteries.

The olive is highly praised locally as a "blessed tree" (alshajart al-mubraka) and is mentioned several times in the Quran [[51]:34-39], in North Africa people say that the olive "looks towards heaven to praise God" and a cut, of even unproductive twigs hearted their deep religious feelings [[52]:512-513].

The date palm has notable religious importance in Islam [[51]:22-27] everyone who has performed the Haj pilgrimage decorates the entrance to his house with an "arch" of palm fronds. Anyone entering the house has to pass under these branches. Palm branches are carried in front of every Muslim funeral procession (in Palestine) and later laid over the grave. Four such branches are put into the ground, one at each corner of the tomb, in such a way that their tops touch each other. Often these branches are interwoven with flowers. It is a common belief that as long as they remain green the deceased is able to praise God. In this way God partly, or wholly, forgives the deceased for his misdeeds in life. Many tombstones have small palm branches engraved on them [[53]:153]. Graves are copiously adorned with palm fronds by visitors to cemeteries during festivals such as Id El Fitr at the end of the Ramadan (A. Dafni Acre, Oct. 2004, personal observation).

5. The trees do not regenerate after cutting - Scholars have explained the mourning symbolism of cypress by the fact that it does not send up new shoots after having been cut [[54]:192].

6. Relation to the underworld - The cypress, called by Greeks and Romans alike "the mournful tree", was also sacred to the rulers of the underworld, and to their associates, the Fates and the Furies. Accordingly it was customary to plant it by the grave, and, in the event of a death, to place it either before the house or in the vestibule, to warn those about to perform a sacred rite against entering a place polluted by a dead body [[47]:39;55:XVI, 60; [56]: IV, 507; ]. According to Ovid [[57], X: 106-142], this tree was named after Kyparissos, Apollo's favourite. This young boy accidentally slew his beloved stag. The boy was struck with such anguish that he besought the gods to doom his life to everlasting gloom. They, in compliance, transformed him into a cypress tree.

7. Mythical powers - In Antiquity the laurel was seen as physically and morally purifying [[45]: 288$290,293,302]$. Laurel was used in funeral rites as an attempt to preserve the continued vitality and strength of the Roman people because it is an emblem of prosperity and agricultural productivity [[3]:107-108].

In conclusion, our findings on the occurrence of plants in graveyards reflect the geographic situation of Israel as a crossroads in the cultural arena between Asia and Europe. Most of the traditions are common to the whole Middle East showing high relatedness to the Greco-Roman as well as to the present-day Europe.

As endemic tradition we can indicate the essential role of S. fruticosa as the main plant used at all human rites of passage symbolizing the human life cycle. Rosemary is of European origin while the use of basil is of Indian influence.

The use of white flowers as cemetery plants may reflect an old European influence and almost the same species are used or their congeners.

The cypress is the main Muslim cemetery' tree as in ancient as well as modern European cultures. The date palm and the olive, the next most prevalent trees in cem- 
eteries, reflect the status of these two species in the Quran as blessed trees.

\section{Appendix}

List of the cited informants.

The number after the name indicates the age of the informant followed by the name of village and the date of the interview.

1. Shukri Araf, 62, Maeelia, 26.6.00.

2. Hamud Jaudat, 30, Kabul, 18.8.00.

3. Zaher Mahra, 40, Acre, 20.8.00,

4. *Amana Halifi, 63, Iblin, 1.12.00.

5. Sheikh Hussien Shahin, 70, Beit Jan, 12.9.00.

6. * Amana Izat Abu el Heija, 73, Kaukab Abu el Heija, 03.07.03,

7. Raja Taha, 54, Deir Hana, 31.12.03.

8. Abbas Mustafa Daud, 82, Dabburieyh, 7.1.04.

9. Jafar Muhammed Sbeikhi, 58, Shibli, 22.1.04

10. Adel Abu Hamid, 57, Kafr Manda, 3.6.04

11. Jafar Muhammed Sbeikhi, Shibli, 67, 22.1. 04.

12. Araf Farooki, 65, Tamra, 2.8.04.

13. Ali El Anan-Abu Khaled, 67, Salame, 2.8.04

14. Makhmud Awad, 68, Tamra, 2.8.04.

15. Abbas Mustafa Daud, 82, Tamra, 2.8.04.

16. Raja El-Hatib, 62, Dier Hana, 02.08.04

17. Tamir Fallakh Mazarib, 35, Mazarib (Beit Zarzir), 11.8.04.

18. Abu Ma'aruf, 75, Bueina-Nujeidat, 16.8.04.

19. Abu Razze, 95, Bueina-Nujeidat, 16.8.04.

20. *Hadi Samiyeh, 90, Mazra'a, 24.8.04

21. Sheikh Akhmed-Abu Ammar, 54, Majdal Kurum 28.8.04.
22. Jamil Abu Raeed Arafat, 71, Mesh'hed, 23.9.04.

23. Abu Khaled Ali El Anan, 67, Salame, 2.9.04

24. Jamil Shibli, Shibli, 34, 1.11.04.

25. Makhmud Kmeidi Abu Ikhia, 57, Shibli, 1.11.04.

26. Makhmud Maslaha-Abu Karem, 57, Daburrieyh, 11.11 .04

27. Mukhamed Taher, 65, Rumana, 23.11.04

28. Mukhamed Ali Fukra, 58, Bueina-Nujeidat, 23.11.04

29. Yusuf Nimmr Massar-Abu Lutuf, 67, Sakhnin, 1.1.05,

30. Muhana Dalashi, 61, Bueina, 1.1.05

31. Nasser Khalil, 68, Sakhnin, 1.1.05

32. Abdaala Ahab, 60, Shibli, 3.1.05.

33. Salman Shibli, 46, Shibli, 3.1.05

34. *Na'amaeh Mukhamad Iktilat, 40, Daburieh, 3.1.05.

35. Ahmed Abu Rakhman Iktilat, 82, Daburieh, 3.1.05

36. Sami Salman Shibli, 31, Daburieh, 1.3.05.

37. Abed Zuabi, 61, Taibe, 28.1.05

38. Ali Zuabi, 30, Taibe, 28.1.05)

39. Mustafa Daud, 56, Shibli, 12.3.05

40. Abdalla Taha, 62, Shibli 12.3.05

41. Fathi Ali,, 55, Arab el Aramshe, 22.3.05

42. Wakhid Ali, 32, Arab el Aramshe, 22.3.05

43. Wahib Ali, 20, Arab el Aramshe, 22.3.05

44. * Rukkiah Maghis, 50, Jordikh, 22.3.05

45. *Umm Ommar, 75, Jordikh, 22, 3.05

46. Akhmed Khaled Khleikhel, 63, Akbara, 28.3.05

47. *Zahara um Mukhmed Khleikhel, 80, Akbara, 28.3.05

48. Sa'eed Makhmud Khsein Khleikhel, 80, Akbara, 28.3.05 
$*^{*}=$ Female

\section{Acknowledgements}

This article is dedicated to all the informants who shared their knowledge with us. The authors would like to express their deepest thanks to Moris Tsemach, Salman Abu Rukan, and Shay Levy for field assistance, and to Prof. Beryl Simpson, Prof. Peter Bernhard, Dr. Idith Fintel-Ginsberg, Dr. Frangiska Megaloudi, Toby Gish, Ron Gish, Marcia Forg and Nimrod Manor for their comments on the various drafts of this paper.

\section{References}

I. Goody J: The Culture of Flowers Cambridge: Cambridge University Press; 1994.

2. Puckle BS: Funeral Customs, their Origin and Development London Werner Laurie; 1926.

3. Fiscelli KA: Plants of life and death: an examination of three plants associated with the cult of the dead. In PhD thesis Chapel Hill: University of North Carolina; 2004.

4. Folkard R: Plant-Lore Legends and Lyrics London: Sampson Low, Morston \& Company; 1892.

5. Vickery R: Plants, death and mourning. In Plant-Lore Studies Edited by: Vickery R. University College London, London; 1984:|80-20I.

6. Buhl MC: The goodness of the Egyptian tree-cult. J Near Eastern Stud 1947, 6:80-97.

7. Jashemski WF: The Gardens of Pompeii: Herculaneum and Villas Destroyed by Vesuvius New York: Caratzas Brothers; 1979.

8. Ovadia Y: Yabi'a Omer (responsa) Jerusalem: Meir Israel; 1993. (In Hebrew)

9. Tritton AS: Muslim funeral customs. B Sch Orient Afr St 1938 9:653-661.

10. Granqvist HN: Muslim Death and Burial: Arab Customs and Traditions Studies in a Village in Jordan Commentationes humanarum literarum. Tomes XXXIV, Nr.I. Helsinki; 1965.

II. Idleman-Smith J, Yazbeck-Haddad Y: The Islamic Understanding of Death and Resurrection Albany: State University of New York; 198I.

12. Spoer HH, Spoer AM: Sickness and death among the Arabs of Palestine. Folklore 1927, 38: I I5-I42.

13. Seaton B: The Language of Flower - A History Charlottesville \& London: University Press of Virginia; 1995.

14. Drury S: Funeral plants and flowers in England: some examples. Folklore 1994, 105:101-103.

15. Cressey D: Birth, Marriage and Death Oxford: Oxford University Press.

16. Dickie J: The Hispano-Arab garden its philosophy and function. B Sch Orient Afr St 1969, 31:237-248.

17. Drower ES: The Mandaeans of Iraq and Iran: Their Cults, Ccustoms, Magic, Legends, and Folklore Leiden: Brill; 1962.

18. Conder J: A Popular Description of Turkey London: Duncan, Tegg \& Sons; 1830.

19. Brun J-P: The production of perfumes in antiquity: the case of Delos and Paestum. Am J Archaeol 2000, 104:277-308.

20. De Cleene M, Lejeune MC: Compendium of Symbolic and Ritual Plants in Europe Volume I and II. Ghent, Belgium: Man and Culture Publishers; 2003.

21. Baumann H: Greek Wild Flowers and Plant Lore in Ancient Greece London: The Herbert Press; 1993.

22. De Gubernatis A: La Mythologie des Plantes Paris: C. Reinwald; 1878.

23. Marzell H: Geschichte und Volkskunde der deutschen Heilpflanzen. Hipokrates

24. Majupuria TC, Joshi DP: Religious \& Useful Plants of Nepal and India Bangkok: Craftsman; 1997.

25. Pandey BP: Sacred Plants of India: Plants for Human Kind New Delhi: Shree; 1989.

26. Simoons JF: Plants of Life, Plants of Death Madison: University of Wisconsin Press; 1998.

27. Zohary M, Grebel I: Myrtle. Encyclopaedia Hebraica 196I, 13:613-614. (In Hebrew)

28. Crowfoot GM, Baldensperger L: From Cedar to Hyssop: A Study in the Folklore of Plants in Palestine London: Sheldon; 1932.

29. Skinner C: Myth and Legends of Flowers, Trees, Fruits and Plants in all Ages and in all Climes Philadelphia and London: B. Lippincott Company; 1911.
30. Vickery R: A Dictionary of Plant-Lore Oxford: Oxford University Press; 1995.

31. Thiselton-Dyer FT: The Folk-Lore of Plants London: Chatto and Windus; 1889.

32. Hutchings $Y$ : Colour in folklore and tradition - the principles. Color Res Appl 2004, 29:57-66.

33. Grieve M: A Modern Herbal New York: Hafner Press; |931.

34. Keister D: Stories in Stone:Aa field Guide to Cemetery Symbolism and Iconography. Layton, Utah: Gibbs Smith; 2004.

35. Murr J: Die Pflanzenwelt in der griechischen Mythologie Innsbruck: Verlag der Wagner'schen Universitäts-Buchhandlung; 1890.

36. Burder T: Religious Ceremonies and Customs London: T Tegg; I84I.

37. Moldenke HN, Moldenke AL: Plants of the Bible New York: Ronald; 1952.

38. Homer : Odyssey Edited by: Mackail WJ. Oxford: Clarendon Press; 1932.

39. Hare'uveni E, Hare'uveni H: The Sea squil (Urginea maritima) and its allies. Hassadeh 1938, 18:295-300. (In Hebrew)

40. Dafni A: Flowers, Herbs and Legends Tel Aviv: Ministry of Defence and Carmel Publishing House; 199I. (In Hebrew)

4I. Donaldson BA: The Wild Rue London: Luzac; 1938.

42. Reid J: Turkey and the Turks London: Robert Tyas; 1840.

43. Jenner H: Christian Symbolism Chicago: AC: McClury \& Company; 1910.

44. Maurin J: Archeologia e storica antica. Napoli 1984, 6:191-208.

45. Ogle J: Laurel in ancient religion and folk-lore. Am J Philology 1910, 3:287-31।.

46. Webber FR: Church Symbolism Detroit: Gale research Company, Book Tower; 1971.

47. Philpot JH: The Sacred Tree or the Tree in Religion and Myth London: McMillan and Co; 1897.

48. Dafni $A$ : Why rags are tied to the sacred trees of the Holy Land? Economic Botany 2002, 56:315-327.

49. Dafni $A$ : On the typology and worship status of sacred trees with a special reference to the Middle East. J Ethnobiol Eethnomed 2006, 2: I-26.

50. Dafni A, Levy S, Lev E: The ethnobotany of Christ's Thorn Jujube (Ziziphus spina-christi) in Israel. Jf Ethnobiol Ethnomed 2005, I:8.

5I. Farooki MIH: Plants of the Quran Lucknow: Sidrah Publishers; 1989.

52. Abu-Zahra N: The rain rituals as rites of spiritual passage. International Journal of Middle East Studies 1988, 20:507-529.

53. Canaan T: Plant-lore in Palestinian superstition. J Palestine Orient Soc 1928, 8:129-168.

54. Ingram IM: Flora Symbolica or the Language and Sentiments of Flowers London: Federick Warne and Co; 1875.

55. Pliny, the elder: Historia Naturalis Edited by: Bostock J, Riley HT. London: Taylor and Francis; 1885.

56. Virgil PVM: The Aneid Edited by: Dryden J. London: The Fido Society; 1993.

57. Ovid : Metamorphoses Edited by: Miller FJ. Harvard: Leob Classical Library, Harvard University Press; 1916.

58. Blech M: Studien zum Kranz bei den Griechen Religionsgeschichtliche Versuche und Vorarbeiten 38. Berlin, New York: Verlag de Gruyter; 1982.

59. Cole J: The History and Antiquities of Filey in the Country of York Scarborough: J. Cole; 1828. (Cited from [14])

60. Litten J: The English Way of Death London: Robert Hale; 1991

61. Baker M: Folklore and Customs of Rural England Newton Abbot, London \& Vancouver: David \& Charles; 1974.

62. Chaudhuri RHN, Pal DC: Plants in folk religion and mythology. In Contribution to Indian Ethnobotany 3rd edition. Edited by: Jain SK. Jodhpur: Scientific Publishers; 1997: 17-24.

63. Manniche L: An Ancient Egyptian Herbal Austin: University of Texas Press; 1989

64. Beckmann S: Root, resin, red and ritual purification - the oil of Terebinth in Eastern Mediterranean Bronze Age cult. Paper presented at the IVth International Congress of Ethnobotany (ICEB 2005) . Istanbul. 17-20.2.05

65. Graves R: The Greek Myths Harmondsworth: Penguin Books; 1955.

66. Smith W: A New Classical Dictionary of Greek and Roman Biography Mythology and Geography London: Heper and Brothers; I85I.

67. Detienne M: The Gardens of Adonis Princeton: Princeton University Press; 1994

68. Addison CG: Damascus and Palmyra: A Journal to the East Philadelphia: EL: Carnet and A: Hart; 1838. 
69. Goodwin G: Gardens of the dead in Ottoman Times. Muqarana 1988, 5:61-69.

70. Euripides, Elektra Edited by: McLeish K. New York: Metheun; 2004.

7I. Lohmann H: Grabmäler auf unteritalischen Vasen Archäologische Forschungen 7. Berlin: Mann Verlag; 1979.

72. Kurtz DC: Athenian White Lekythoi. Patterns and Painters Oxford: Clarendon Press; 1975.

73. Eichberger $\mathrm{Ch}$, Sigl M, Rühfel $\mathrm{H}$ : Trees and shrubs on classical Greek Vases. Bocconea 2005 in press.

74. Burr Thompson D, Griswold RE: Garden Lore of Ancient Athens. Excavations of the Athenian Agora Princeton, New Jersey: American School of Classical Studies at Athens; 1963.

75. Hale N: A History of Modern Greece Boston: Published by the author; 1833.

76. Forster ES: Trees and plants in the Greek tragic writers. Greece Rome 1952, 21:57-63.

77. Frank T: Vergil's apprentice. Classical Philol 1920, 15:23-38.

78. Münzer H: Viaje por Espaòa y Portugal, 1494-1495 Madrid: Polifemo; |991.

79. Miguel ES: Rue (Ruta L., Rutaceae) in traditional Spain: frequency and distribution of its medicinal and symbolic application. Econ Bot 2003, 57:231-244.

80. Feinbrun N, Danin A: Analytical Flora of Eretz Israel Jerusalem: Cana: |99|.

8I. al-Antaki Daud : Tadhkirat Ula li-'Lbab wa 'I-Jami al-'Ujab al-'Ujab. Cairo 1935. (In Arabic)

82. Brenk EE: 'Purpureos Spargem Flores': Greek motif in the Aeneid? Classical Quart 1990, 40:218-223.

83. Tzedakis Y, Martlew H, Eds: Minoans and Mycenaean's. Flavours of Their Time Athens: National Archaeological Museum Exhibition Catalogue. 12/7-27/I I/1999

84. Thomas JJ: Brittania Antiquissima London: HT: Dwight; 1860.

85. Haberson C: An interpretation of the Language of Flowers London: Hooker and Claxton; 1839.

86. Forster SE: Trees and plants in Homer. Classical Rev 1936, 50:97-104.

87. Sheil-Woulfe ML, Sheil J: Glimpses of Life and Manners in Persia London: John Murray; 1856.

88. Fowler G: Three Years in Persia with Traveling Adventure in Koordistan London: Henry Colbrun; I84I.

89. Binning RBM: A Journal of Two Years Travel in Persia, Ceylon etc London: WH: Allen; 1857.

90. Slade A: Records of Travels in Turkey Greece etc London: Allen \& Ticknor; 1833.

91. Slade A: Turkey, Greece and Malta London: Saunders \& Otley; 1837.

92. Olin S: Greece and the Golden Horn London: Phillips \& Co; 1854.

93. Hartley J: Researches in Greece and the Levant London: Seeley and Sons; $|88|$.

94. Wines EC: Two Years and Half in the Navy: Or, Journal of a Cruise in the Mediterranean and Levant London: Carey and Lea; 1832

95. Morris R: Freemasonry in the Holy Land or Handmarks of Hiram Builders, I 875 Kessinger Publications (books.google.com visited 20.8.06).

96. Davies B: A New System Of Modern Geography Or a Genera Description of the MostlRemarkable Countries. Philadelphia and Richmond: Johnson and Warner; 1813 .

97. Geophonia BS: A collection of Agricultural Literature Edited by: Owen T. London: Printed by the Author; 1805

98. Pausanias : Description of Greece: Attica and Corinth, Books I and II Edited by: Jones WHS. Harvard: Loeb Classical Library, Harvard University Press; 1918. Stuttgart: Verlag Maraquardt and Cie; 1938 The Oedipus Coloneus. Translated by Jebb RC: Amsterdam: Adolf M. Hakkert; 1928.

99. Plutarch Parallel Lives. Theseus, Romulus, Lycurgus, Numa, Solon \& Publicola Volume I. Edited by: Beradott P, Perrin B. Harvard: Leob Classical Library, Harvard University Press; 1914.

100. Petronius C: The Satyricon Edited by: Allison AR. New York: The Penurge Press; 1930.

10I. Seneca LA: Tragedies II: Oedipus, Agamemnon, Thyestes, Hercules on Oeta, Octavia Edited by: Fitch JG. Harvard: Loeb Classical Library No.78. Harvard Classical Library; 2004.

102. Ogle MB: The house door in Greek and Roman religion and folklore. Am J Philology I9II, 32:25I-27I.

103. Lamb RW: Some poetical forests. Greece and Rome 1950, 19:29-35.

104. Burries EE: The nature of taboo and its survival in Roman life. Classical Philology .
105. Koehn A: Chinese flower symbolism. Monu Nippon 1952, 8: $|2|-\mid 46$.

106. Sophocles: The Plays and Fragments with Classical Notes and Commentary. Part 2.

107. Buchanan-Brown J: Three Prose Works: Miscellanies; Remains of Gentilisme and Judaisme, Observations Edited by: Aubery-Fontwell J. Centaur Press; 1972.

108. Webster J: Travels through the Crimea, Turkey and Egypt Performed during the Years 1825-1828 London: Henry Coburn and Richard Bentley; 1830 .

109. Bush G: Illustrations of the Holy Scripture Philadelphia: Lippincott, Grambo et al; 1854

1 10. Davies B: A New System of Modern Geography; Or a General Description of the Most Remarkable Countries Philadelphia and Richmond: Johnson and Warner; 1813.

III. Pelt M: Des Fruits Paris: Editions J'ai bu; 2000.
Publish with Biomed Central and every scientist can read your work free of charge

"BioMed Central will be the most significant development for disseminating the results of biomedical research in our lifetime. " Sir Paul Nurse, Cancer Research UK

Your research papers will be:

- available free of charge to the entire biomedical community

- peer reviewed and published immediately upon acceptance

- cited in PubMed and archived on PubMed Central

- yours - you keep the copyright
BioMedcentral 